\title{
Decision support for build-to-order supply chain management through multiobjective optimization
}

\author{
S. Afshin Mansouri ${ }^{1 *}$, David Gallear ${ }^{1}$ and Mohammad H. Askariazad ${ }^{2}$ \\ 1: Brunel Business School, Brunel University \\ 2: School of Management, Sharif University of \\ Uxbridge, Middlesex UB8 3PH \\ United Kingdom \\ Technology International Campus, Kish Island, \\ Iran
}

(Accepted version, published in International Journal of Production Economics, 135 (2012) 24-36)

\begin{abstract}
This paper aims to identify the gaps in decision-making support based on multiobjective optimization (MOO) for build-to-order supply chain management (BTO-SCM). To this end, it reviews the literature available on modelling build-toorder supply chains (BTO-SC) with the focus on adopting MOO techniques as a decision support tool. The literature has been classified based on the nature of the decisions in different part of the supply chain, and the key decision areas across a typical BTO-SC are discussed in detail. Available software packages suitable for supporting decision making in BTO supply chains are also identified and their related solutions are outlined. The gap between the modelling and optimization techniques developed in the literature and the decision support needed in practice are highlighted. Future research directions to better exploit the decision support capabilities of MOO are proposed. These include: reformulation of the extant optimization models with a MOO perspective, development of decision supports for interfaces not involving manufacturers, development of scenarios around service-based objectives, development of efficient solution tools, considering the interests of each supply chain party as a separate objective to account for fair treatment of their requirements, and applying the existing methodologies on real-life data sets.
\end{abstract}

Key words: Supply chain management; Build-to-order; Decision support; Multiobjective optimization; Pareto-optimal front.

\footnotetext{
* Corresponding author. Email: Afshin.Mansouri@brunel.ac.uk; Tel: +44-1895-265361; Fax: +441895-269775
} 


\section{Introduction}

A build-to-order supply chain (BTO-SC ${ }^{1}$ ) is a production system that delivers goods and services based on individual customer requirements in a timely and cost competitive manner (Gunasekaran \& Ngai 2009). Build-to-order and configure-toorder markets, driven by mass customization and e-commerce, force retailers and manufacturers to shorten planning cycles, reduce manufacturing lead time, and expedite distribution (Tyan \& Duc 2003). The available evidence indicates that BTO has significant business potential to promote sales and cost savings. It allows for improved customer satisfaction and provides an opportunity for massive savings in inventory costs (Sharma \& LaPlaca 2005). According to a U.S. survey, 74\% of car buyers in the U.S. would prefer to order a customized vehicle rather than buy from a dealer's inventory if they could get delivery in less than 3 weeks (Business Wire, 2001 cited in Christensen et al. 2005). Nissan Motor estimated that a full implementation of a BTO strategy could save up to $\$ 3600$ per vehicle (Economist, 2001 cited in Christensen et al. 2005). Dell, arguably the pioneer of BTO in the PC industry, generated a $160 \%$ return on its invested capital by allowing customers to order customized computers online, which were then manufactured and delivered within 5 days (The Wall Street Journal, 1999 cited in Ghiassi \& Spera 2003). Autoliv, the vehicle safety system provider, reduced $37 \%$ of their plant inventory by coordinating orders online with suppliers (The Wall Street Journal, 2001 cited in Swaminathan \& Tayur 2003).

Efficient management of BTO-SCs has attracted the attention of researchers and practitioners following successful implementation by companies like Dell, Compaq and BMW (Gunasekaran \& Ngai 2005). Considering the growing importance of more informed and timely decision making in BTO-SCs, Gunasekaran \& Ngai (2009) encourage further research on the modelling and analysis of such systems. They classify the BTO-SC decisions into: $i$. configuration and ii. coordination levels. Furthermore, they emphasize the importance of further research in several directions in BTO-SCM including: developing suitable planning and scheduling models and techniques for managing the material flow, and modeling and analysis of the coordination-level issues (Gunasekaran \& Ngai 2009).

\footnotetext{
${ }^{1}$ A comprehensive list of acronyms used in the paper is provided in Appendix A
} 
In order to expand BTO market share, several aspects of operations management need fundamental improvement. The German car industry for instance, has invested a lot of effort in recent years to further increase this share via shorter delivery times, high delivery reliability and a faster responsiveness (Meyr 2004). The current trend within the German automotive industry from build-to-stock (BTS) to BTO is mostly a shift in the 'order share' from retailers' forecast of market orders towards real customers' confirmed orders (Meyr 2004). Major strategic goals include: shorter delivery lead times, more reliable promised due dates and flexibility in accepting change of customer options in very short time (Stautner 2001 cited in Meyr 2004). Furthermore, it is evident that the BTO market is not restricted to standard or premium products any more. In particular, it is becoming popular in the retail industry with the rapid growth of internet shopping. For instance, Ewatchfactory ${ }^{2}$ (a watch manufacturer) and timbuk $2^{3}$ (a bag producer) allow customers to design their own products (Swaminathan \& Tayur 2003).

With these emerging trends, timely and informed decision making is becoming crucial for the longterm success of businesses. However, different members of a BTO-SC may have their own preferences in response to dynamic customer orders which in many cases are likely to be conflicting. Effective decision support is thus essential to enable interested parties to evaluate the consequences of countless decisions being made, in real time, across the whole supply chain. Effective decision support would help business opportunities to be exploited and help to solidify collaboration in the chain. The current global economic downturn has further emphasized the importance of optimization to support managerial decision making to maintain competitive advantage towards business goals.

The main contributions of this paper can be summarized as follow:

- our work has identified the gaps in the theoretical research for applying multiobjective optimization (MOO) as part of a decision support system (DSS) for BTO-SCM;

\footnotetext{
${ }^{2}$ www.ewatchfactory.com

${ }^{3}$ www.timbuk2.com
} 
- our work has identified the existing body of literature in the field of optimization in either BTO-SCM, or general SCM with a dyadic or network perspective (i.e. with two or more parties involved in decision making);

- the papers with a combined BTO and dyadic/network perspective have been further analyzed from different perspectives (decision type, decision interface, nature of objectives, solution tools and source of data), thus providing a systematic review and classification;

- central to the goals of our analysis, we have distinguished between MOO and non-MOO papers, thus identifying non-MOO optimization problems that have the potential to be reformulated as MOO instances;

- we provide an analysis of the aforementioned literature that identifies the main foci of the links among supply chain parties where optimization has been applied. By doing this, we have also identified the gaps that need future attention; and

- we provide an initial analysis of existing software packages to establish to what extent they provide MOO-based decision support for the BTO context.

The organization of this paper is as follows: Section 2 discusses decision making in BTO-SCs and the role of multi-objective optimization in this regard. The research methodology is presented in Section 3. Section 4 reviews five different decision problems in BTO supply chains and discusses optimization modelling techniques used in this field. Section 5 presents various software packages capable of solving relevant BTO decision problems. Finally, Section 6 presents our discussion and proposes future directions and further extensions in modelling and optimizations of BTO supply chains.

\section{Decision making in BTO-SC}

A BTO-SC is primarily formed to create a sustainable competitive advantage for all members of the supply chain which is ultimately measured by success in the market (Christensen et al. 2005). However, the interests of all players are not necessarily in line with each other and therefore, cannot be fully satisfied all the time. As a result, management of BTO-SCs necessarily involves extensive compromise and trade-offs due to inherent conflict among the different parties. For example, customers might 
look for reduced price and shorter delivery lead times while manufacturers try to enhance utilization of their facilities with reduced inventory and setup changeover. Similarly, suppliers may favor smooth demand whereas logistic providers will look for high fleet utilization. It is obvious that all of these objectives cannot be attained at the same time. We argue that multi-objective optimization (MOO) has significant potential to facilitate decision-making in such instances by provision of insights as to the consequences of any action taken towards satisfying one performance metric on the rest of objectives. The key role of MOO in this scenario is to find the set of nondominated solutions (i.e. solutions that cannot be outperformed in all performance metrics by other solution(s)) from which decision makers can choose based on their preferences. Figure 1 shows a conceptual framework for decision making in a typical BTO-SC. The model is a simplified illustration of interfaces between a manufacturer and other parties, i.e: customer(s), supplier(s), logistic provider(s) and distributer(s) where MOO can act as a decision support to facilitate better informed decision making. Other interfaces, for instance a three-way interface between supplier, manufacturer and logistics provider could also be incorporated in the model. We have not incorporated such interfaces at this stage for the sake of simplicity.

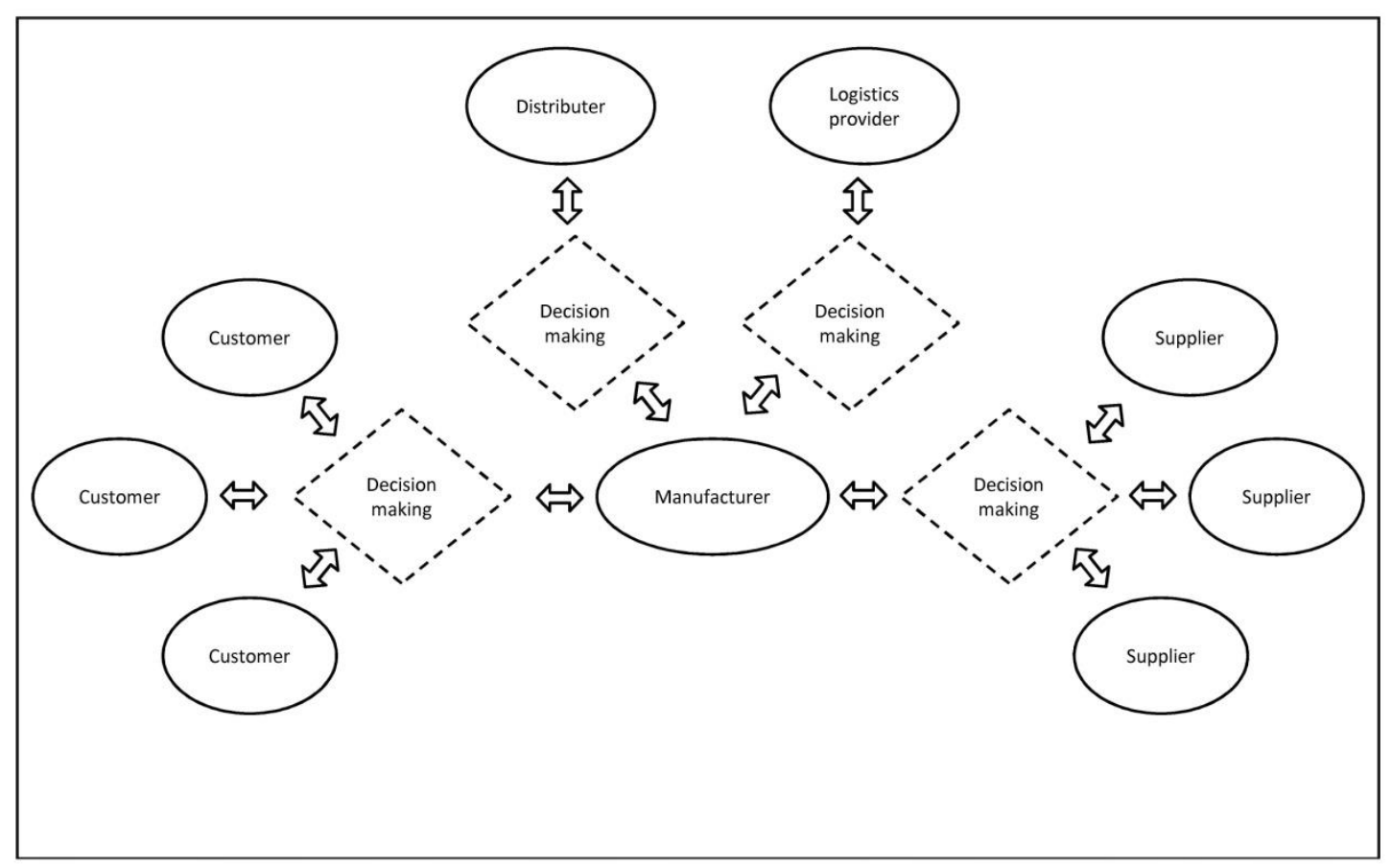

Figure 1. The conceptual decision model for BTO-SC. 


\subsection{Decision support for BTO-SC}

Higher levels of responsiveness to the changes in customer demands, a cost effective production scheme for a small volume of product, as well as fast and reliable distribution methods are the key success factors of the BTO-SC (Chow et al., 2007).

To achieve this, multiple independent SC members may take joint decisions on production and logistics for large parts of their collective supply chain work (Akkermans et al., 2004) which requires both information and knowledge flow for supporting decision-making (Choi and Hong, 2002).

Little (2004) defines a Decision Support System (DSS) as a "model-based set of procedures for processing data and judgments to assist a manager in his decision making." Bonczek et al. (1980) define a DSS as a computer-based system consisting of three interactive components: a language system, a knowledge system, and a problem-processing system. Turban and Aronson (2001) argue that the basis for defining DSS has been developed from the perceptions of what a DSS does (such as support decision making in unstructured problems) and from ideas about how the DSS's objective can be accomplished (such as components required, appropriate usage pattern, and necessary development processes). In general, a DSS application contains four main components: Database (DB), Model Base (MB), Knowledge Base (KB), and a Graphical User Interface (GUI) (see Figure 2). The database stores the data, model and knowledge bases store the collections of models and knowledge, respectively, and the GUI allows the user to interact with the database, model base, and knowledge base. The knowledge base may contain simple search results for analyzing the data in the database.

The model base comprises the models used to perform optimization, simulation, or other algorithms for advanced calculations and analysis. These models allow the decision support system to not only supply information to the user but aid the user in making a decision. While there is substantial literature on database, knowledge base, and GUI (Chow et al., 2007; Sharif et al., 2007), in this research we are interested in analyzing optimization techniques that have been applied in the model base component of DSSs to support decisions in BTO-SC. 


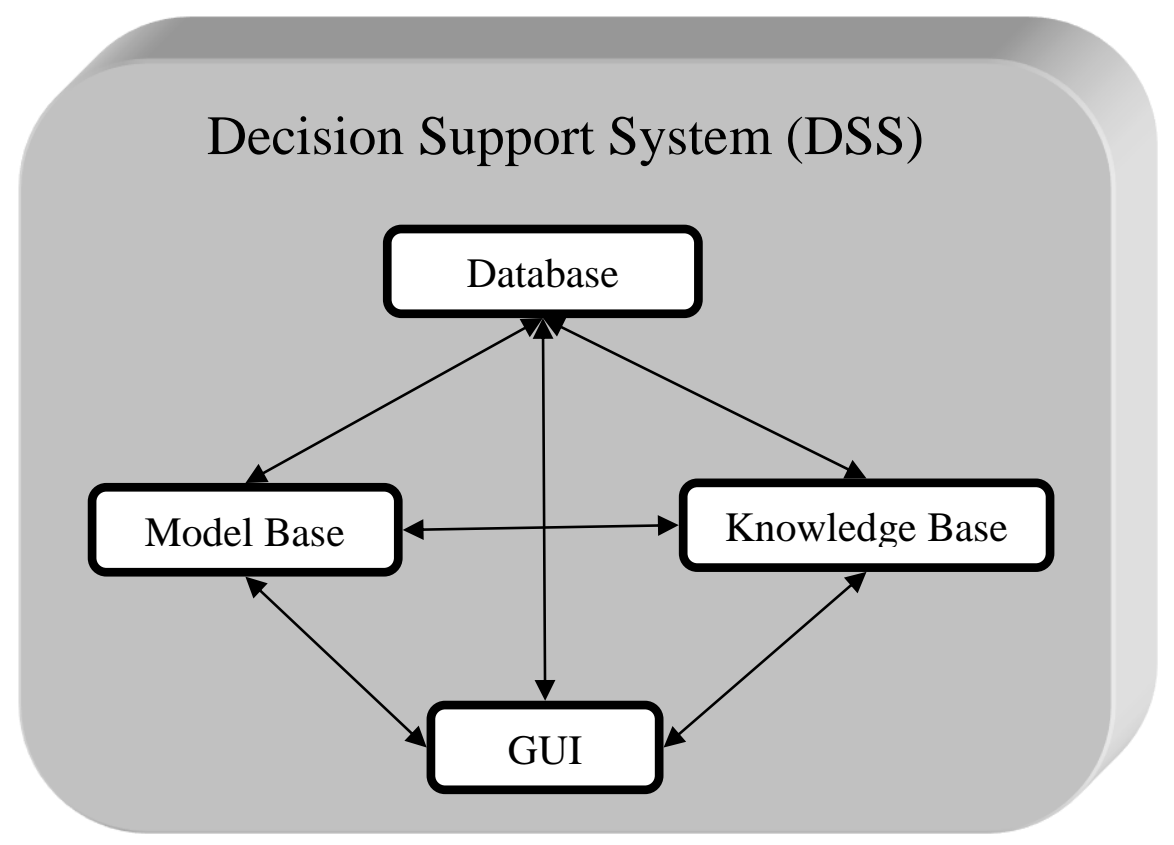

Figure 2. A schematic view of a typical decision support system

\subsection{Multiobjective optimization and decision support}

The multiobjective optimization problem (MOOP) can be defined as the problem of finding a vector of decision variables $\tilde{x}$, which optimizes a vector of $M$ objective functions $f_{i}(\tilde{x})$ where $i=1,2, \ldots, M$; subject to inequality constraints $g_{i}(\tilde{x}) \geq 0$ and equality constraints $h_{k}(\tilde{x})=0$ where $j=1,2, \ldots, J$ and $k=1,2, \ldots, K$.

The set of objective functions constitute a multi-dimensional space in addition to the usual decision space. This additional space is called the objective space, $Z$. For each solution $\tilde{x}$ in the decision variable space, there exists a point in the objective space:

$$
\tilde{f}(\tilde{x})=Z=\left(z_{1}, z_{2}, \ldots, z_{M}\right)^{T}
$$

In a MOOP, we wish to find a set of values for the decision variables that optimizes a set of objective functions. A decision vector $\tilde{x}$ is said to dominate a decision vector $\tilde{y}$ (also written as $\tilde{x}>\tilde{y}$ ) if:

$$
f_{i}(\tilde{x}) \leq f_{i}(\tilde{y}) \quad \forall i \in\{1,2, \ldots, M\}
$$

and

$$
\exists i \in\{1,2, \ldots, M\} \quad \mid f_{i}(\tilde{x}) \leq f_{i}(\tilde{y})
$$

All decision vectors that are not dominated by any other decision vector are called nondominated or Pareto-optimal and constitute the Pareto-optimal front. These are 
solutions for which no objective can be improved without detracting from at least one other objective.

There are several approaches to find the Pareto-optimal front of a MOOP. Among the most widely adopted techniques are: sequential optimization, $\varepsilon$-constraint method, weighting method, goal programming, goal attainment, distance based method and direction based method. For a comprehensive study of these approaches, readers may refer to Collette \& Siarry (2004). Considering the complexity of MOOPs, metaheuristics and in particular Evolutionary Algorithms (EAs) have extensively been used to find approximations of Paretooptimal frontiers of large-sized problems. Interested readers for detailed discussion on application of EAs in MOO are referred to Coello Coello et al. (2002) and Deb (2001).

\subsection{A generic example}

To elaborate on the potential of $\mathrm{MOO}$ in facilitating negotiations and decision making, we make use of a generic due date promising problem between a customer and a manufacturer. The potential customer is considering to place an order for a customized product. The manufacturer offers a selling price, possibly beyond the customer's budget, based on a fixed due date or delivery lead time. The customer might not be happy with the combination of price and due date and therefore, may be reluctant to place the order. The potentially missed opportunity for the manufacturer could have been avoided if the original price offered could be negotiated at the expense of an increased due date. This scenario could well be formulated as a MOOP with the following set of objectives:

$$
\text { Minimize }\left(f_{1}=\text { cost, } f_{2}=\text { due date }\right)
$$

Figure 3 illustrates a schematic representation of the Pareto-optimal front for this problem obtained via MOO. An option b is initially offered to the customer. Based on the trade-off analysis, it is revealed that by only $10 \%$ increase in the delivery time at point a, a 30\% reduction in cost could be offered to the customer. This might interest the customer and result in the purchase of the product. On the other hand, customers who desire a speedy delivery might be willing to pay extra to compensate for overtime working hours. Such scenarios could be evaluated on the trade-off curve. 


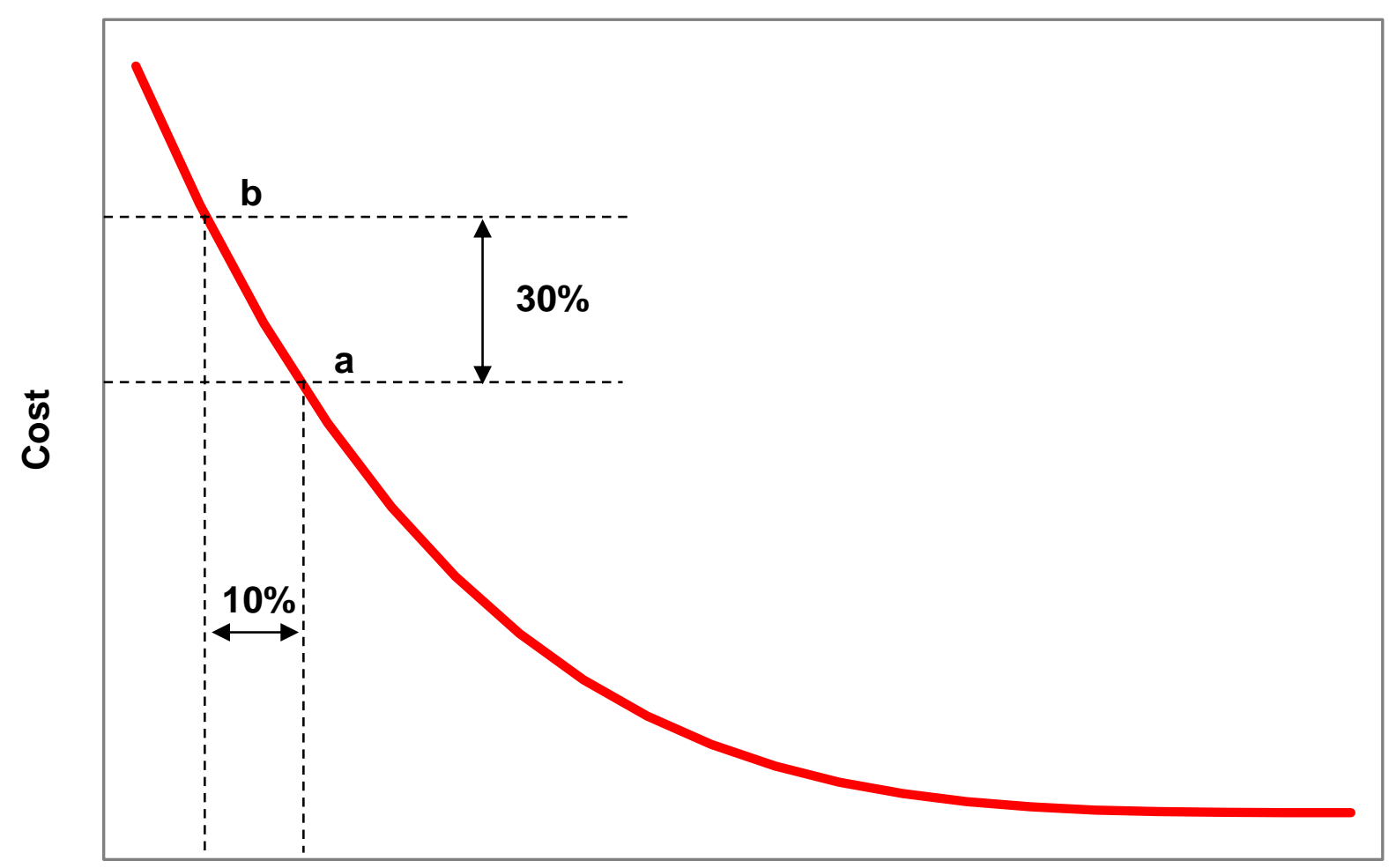

\section{Due date}

Figure 3. Trade-off between cost and due date as a Pareto-optimal front. Faster deliveries can be promised at higher cost while lower cost can be offered with longer lead times.

This example indicates how MOO can contribute to the long term business goals of actors in the supply chain. Such decision aids need to be configured and made available to the respective decision makers in a short time, for example to meet the requirements of on-line shopping in a BTO-SC. For this, efficient solution tools are crucial to the success of MOO as a practical decision support.

\section{Research methodology}

In this research, a literature survey approach has been employed as the research methodology for studying the applications of MOO as a decision aid for managing BTO-SCs. The literature on both MOO and BTO-SC has been collected primarily from high ranking journals in the fields of management science, operation research, operations management and supply chain management. The literature search was conducted using combinations of keywords such as: build to order, make to order and configure to Order, just in time, mass customization, quick response and postponement, along with optimization and/or multi objective optimization. We used 
the following journals to collect the literature on applications of optimization and MOO in the supply chain context: International Journal of Production Economics, European Journal of Operational Research, International Journal of Production Research, Journal of Operations management, Management Science, Production and Operations Management, Production Planning \& Control, Production, Manufacturing and Logistics, Computers \& Industrial Engineering, IEEE Transactions on Systems, Man and Cybernetics, and Annals of Operations Research. From these sources, relevant references to other resources were identified and included in the survey.

The majority of the literature in the area of supply chain planning and scheduling considers the traditional make-to-stock (MTS) environment (Demirli and Yimer, 2008). Furthermore, many researchers have developed local optimization models by focusing on just one part (echelon) of the supply chain. We, however, were interested in the use of mathematical modelling techniques between links in the supply chain.

Our main purpose is to examine the potential of MOO as a decision support in the BTO supply chain context. Our goal was to examine the literature from multiple perspectives in order to identify both (a) the existing applications of MOO in the BTO supply chain context, but also (b) to identify candidate applications for MOO in the BTO supply chain context. The former was, by definition, clearly defined, that is literature contributions incorporating the use of $\mathrm{MOO}$ in a BTO environment.

The latter (i.e. (b)) required broader searching and filtering of the literature as, by implication the candidates would not necessarily be explicitly labelled with MOO or BTO. As mentioned above, in our conceptualization, to qualify as a candidate for the application of MOO as a decision support in the BTO supply chain context, the optimization problem needed to include the objectives of at least two parties in the supply chain. In other words, the multiobjective nature of the optimization problem was that it incorporated either a dyadic or a network perspective. A single echelon problem (non-dyadic or -network) did not qualify. Thus, in our conceptualization, MOO is tied to the context of the decision problem - multiobjective refers to the presence of the (competing) objectives of more than one supply chain party. 
Hence, in the first instance we were interested in identifying any literature contributions that have dealt with optimization in the BTO environment. Next, we were interested in identifying any literature contributions that have dealt with supply chain related optimization problems in which more than two parties are involved in the decision making (contributions not explicitly labelled as being in the BTO environment, but might or might not be). Thus, using these search strategies, 46 papers were selected that met one or more of the following two classification criteria (Table 1):

i. Type of supply chain: papers that analyze BTO supply chain.

ii. Level of analysis: papers that concern supply chain in a dyadic or network perspective, where a dyadic (or network) perspective reflects the involvement of two or more parties in the decision problem.

Table 1 provides a summary of the issues addressed in these papers. It further specifies for each paper whether a BTO and/or dyadic/network relation have been considered. These are indicated by $\checkmark$ and $\mathbf{X}$ symbols in the last two columns.

Of the 46 papers, 6 neither analyze BTO-SC situations nor view the decision problem from a dyadic or network perspective, thus were not considered for further investigation in this research. From the remaining 40 papers, 18 were identified that whilst dealing with optimization problems involving two or more parties, were not explicitly labelled as being in the BTO supply chain context. Our close examination of these 18 papers revealed that in fact none were concerned with a BTO environment. Although not of interest for our subsequent analysis, we had nevertheless identified 18 general supply chain context candidates for the application of MOO. This itself is a valuable contribution.

\section{Review of decision problems and modelling techniques in BTO-SC}

This section reviews in more detail a subset of papers from Table 1 which address optimization of BTO-SCs with dyadic or network perspective. These include 22 papers with a $\checkmark$ sign in the last two columns of Table 1. These papers employ various optimization models for decision making in different parts of supply chain. 
Our detailed analysis is summarised in Table 2. The optimization/decision problem addressed in the papers represent the decision types which we use as a criterion for sub-classifying the papers. These decision types include: order promising or due-date assignment, procurement and inventory control, production planning and scheduling, network design and product design. It is important to explain here that this classification has been developed through an iterative process of reviewing the 22

Table 1. Summary of the papers addressing either (i) a BTO problem and/or (ii) a general SCM problem with a dyadic or network perspective

\begin{tabular}{|c|c|c|c|}
\hline Authors & Issues addressed & BTO & $\begin{array}{l}\text { Dyadic or } \\
\text { network }\end{array}$ \\
\hline $\begin{array}{l}\text { Kingsman et al. } \\
\text { (1996) }\end{array}$ & Customer enquiries in MTO companies & $\checkmark$ & $\mathbf{x}$ \\
\hline Wang et al. (1998) & Due-Date negotiations for the MTO manufacturing & $\checkmark$ & $\checkmark$ \\
\hline $\begin{array}{c}\text { Moodie and } \\
\text { Bobrowski (1999) }\end{array}$ & Trade-off negotiation between price and delivery & $\checkmark$ & $\mathbf{x}$ \\
\hline $\begin{array}{l}\text { Easton, and Moodie } \\
\qquad(1999)\end{array}$ & $\begin{array}{l}\text { Pricing and lead time decisions for MTO firms with } \\
\text { contingent orders }\end{array}$ & $\checkmark$ & $\checkmark$ \\
\hline Chen et al. (2001a) & Quantity and due-date quoting in ATP & $\checkmark$ & $\checkmark$ \\
\hline $\begin{array}{l}\text { Hegedus and Hopp } \\
\qquad(2001)\end{array}$ & Due-date setting with supply constraints using MRP & $\checkmark$ & $\checkmark$ \\
\hline Chen et al. (2001b) & Coordination mechanisms for distribution systems & $\mathbf{x}$ & $\checkmark$ \\
\hline Agnetis et al. (2001) & Set-Up coordination in two stages of SC & $\mathbf{x}$ & $\checkmark$ \\
\hline Joines et al. (2002) & Multiobjective simulation optimization in SC & $\mathbf{x}$ & $\checkmark$ \\
\hline $\begin{array}{l}\text { Song and Yao } \\
\qquad(2002)\end{array}$ & $\begin{array}{l}\text { Performance analysis and optimization of ATO with } \\
\text { random lead times }\end{array}$ & $\checkmark$ & $\mathbf{x}$ \\
\hline Rajagopalan (2002) & Modelling and application of MTO and MTS & $\checkmark$ & $\checkmark$ \\
\hline Chen et al. (2002) & Batch AATP modelling & $\checkmark$ & $\checkmark$ \\
\hline Chena et al. (2003) & Design of BTO/CTO shop floor control systems & $\checkmark$ & $\mathbf{x}$ \\
\hline Zhoua et al. (2003) & $\begin{array}{l}\text { Bi-criteria allocation of customers to warehouses using } \\
\text { GA }\end{array}$ & $\mathbf{X}$ & $\checkmark$ \\
\hline Sadeh et al. (2003) & Decision support for Agent-Based E-Supply Chain & $\mathbf{x}$ & $\checkmark$ \\
\hline $\begin{array}{c}\text { Masaru and } \\
\text { Masahiro (2003) }\end{array}$ & $\begin{array}{l}\text { Supply planning optimization under uncertain demand } \\
\text { using GA }\end{array}$ & $\mathbf{x}$ & $\checkmark$ \\
\hline Ha et al. (2003) & Price and delivery logistics competition in a SC & $\checkmark$ & $\checkmark$ \\
\hline Moses et al. (2004) & Real-time due-date promising in BTO environments & $\checkmark$ & $\checkmark$ \\
\hline Pibernik (2005) & $\begin{array}{l}\text { AATP methods for operations and inventory } \\
\text { management }\end{array}$ & $\checkmark$ & $\checkmark$ \\
\hline $\begin{array}{l}\text { Mukhopadhyay and } \\
\text { Setoputro (2005) }\end{array}$ & $\begin{array}{l}\text { Optimal return policy and modular design for BTO } \\
\text { products }\end{array}$ & $\checkmark$ & $\checkmark$ \\
\hline $\begin{array}{l}\text { Kawtummachaiand } \\
\text { Hop (2005) }\end{array}$ & Order allocation in a multiple-supplier environment & $\mathbf{x}$ & $\checkmark$ \\
\hline Andersona et al. & MOO for operational variables in a waste incineration & $x$ & $\checkmark$ \\
\hline
\end{tabular}


(2005)

Xue et al. (2005)

Watanapa and Techanitisawad (2005)

Lu and Song (2005)

plant

DSS for design-supplier-manufacturing planning with MOEA

Price and due date settings for multiple customer classes

Order-based cost optimization in ATO

Table 1. Continued from previous page

\begin{tabular}{|c|c|c|c|}
\hline Authors & Issues addressed & ВТО & $\begin{array}{l}\text { Dyadic or } \\
\text { network }\end{array}$ \\
\hline Zhao et al. (2005) & $\begin{array}{l}\text { Optimization-based ATP with Multi-stage resource } \\
\text { availability }\end{array}$ & $\checkmark$ & $\checkmark$ \\
\hline $\begin{array}{l}\text { Venkatadria et al. } \\
\qquad(2006)\end{array}$ & Optimization-based DSS for order promising & $\checkmark$ & $\checkmark$ \\
\hline Ding et al. (2006) & $\begin{array}{l}\text { Simulation-based MOGA approach for networked } \\
\text { enterprises optimization }\end{array}$ & $\checkmark$ & $\checkmark$ \\
\hline $\begin{array}{l}\text { Lamothe et al. } \\
\qquad(2006)\end{array}$ & Product family selection and SC design & $\checkmark$ & $\checkmark$ \\
\hline $\begin{array}{l}\text { Amodeo et al. } \\
\qquad(2007)\end{array}$ & Multiobjective supply chain optimization & $x$ & $\checkmark$ \\
\hline $\begin{array}{l}\text { Babu and Gujarathi1 } \\
\qquad(2007)\end{array}$ & $\begin{array}{l}\text { MODE for optimization of SC planning and } \\
\text { management }\end{array}$ & $\mathrm{x}$ & $\checkmark$ \\
\hline Serrano et al. (2007) & SC disruptions management with the NSGA-II & $x$ & $\checkmark$ \\
\hline Aigbedo (2007) & $\begin{array}{l}\text { Effect of MC on suppliers' inventory levels in JIT } \\
\text { manufacturing systems }\end{array}$ & $\checkmark$ & $\checkmark$ \\
\hline Selim et al. (2008) & Collaborative production-distribution planning in SC & $\mathbf{x}$ & $\checkmark$ \\
\hline $\begin{array}{l}\text { Demirli and Yimer } \\
\qquad(2008)\end{array}$ & Fuzzy scheduling of BTO SC & $\checkmark$ & $\checkmark$ \\
\hline $\begin{array}{l}\text { Crnkovic et al. } \\
\qquad(2008)\end{array}$ & DSS for exploring SC tradeoffs & $x$ & $\checkmark$ \\
\hline Galasso et al. (2008) & DSS for SC planning under uncertainty & $x$ & $\checkmark$ \\
\hline Zhou et al. (2009) & $\begin{array}{l}\text { Product configuration optimization in ATO } \\
\text { manufacturing }\end{array}$ & $\checkmark$ & $\checkmark$ \\
\hline $\begin{array}{l}\text { Nagarajan and } \\
\text { Bassok (2008) }\end{array}$ & $\begin{array}{l}\text { A bargaining framework for the assembly problem in } \\
\text { SC }\end{array}$ & $x$ & $\checkmark$ \\
\hline Sahin et al. (2008) & MPS policy and rolling schedules in a two-stage MTO & $\checkmark$ & $\checkmark$ \\
\hline $\begin{array}{l}\text { Stefansson et al. } \\
\text { (2009) }\end{array}$ & $\begin{array}{l}\text { Risk reduction of delayed deliveries in MTO } \\
\text { production }\end{array}$ & $\checkmark$ & $\checkmark$ \\
\hline $\begin{array}{l}\text { Amodeo et al. } \\
\qquad(2009)\end{array}$ & $\begin{array}{l}\text { Multiobjective simulation-based optimization for } \\
\text { inventory management using Methaheuristic }\end{array}$ & $\mathbf{x}$ & $\checkmark$ \\
\hline Ding et al. (2009) & $\begin{array}{l}\text { Stochastic multiobjective production-distribution } \\
\text { network design }\end{array}$ & $\checkmark$ & $\checkmark$ \\
\hline $\begin{array}{l}\text { Rudberg and Thulin } \\
\text { (2009) }\end{array}$ & Centralised SC master planning employing APS & $x$ & $\checkmark$ \\
\hline
\end{tabular}


Song and Kusiak Pareto-optimal modules for delayed product

(2010) differentiation

Graman (2010) Partial-postponement decision cost models

MTO = Make-to-Order; NSGA = Nondominated Sorting Genetic Algorithm; GA = Genetic Algorithm; MTS = Make-to-Stock; MOEA = Multiobjective Evolutionary Algorithm; $\mathbf{S C}=$ Supply Chain; $\mathbf{B T O}=$ Build-to-Order; $\mathbf{M O D E}=$ Multiobjective Differential Evolution; $\mathbf{A T P}=$ Available-to-Promise $\mathbf{M C}=$ Mass Customization; $\mathbf{A A T P}=$ Advanced Available-to-Promise; ATO $=$ Assemble-to-Order; MOO = Multiobjective Optimization; MRP = Material Requirements Planning; DSS = Decision Support System; MPS = Master Production Schedule; APS = Advanced Planning System .

papers. Initially, as guidance, seven decision types were chosen based on the general knowledge of operations management and SCM. These were then reduced to the final five categories as we proceeded with the review. These decision type categories are shown in column 1 in Table 2.

For each problem type, the decision interfaces representing the actors involved in the decision making are identified (column 2). The papers in each interface are then described with more details as to their objectives, key decision variables, the optimization/analytical technique and the nature of the data used for validating the approach. In order to provide more insights as to the nature of objectives considered in the models, they are classified into the following categories (column 3):

- category M: Money-based objectives. This category represents objectives defined around metrics like cost and profit;

- category S: Service-based objectives. Aspects of customer service are reflected in this category by means of metrics such as due date, lateness and stock-out; and

- category O: Operation-based objectives. Those objectives which improve efficiency of operations are listed in this category and include metrics such as production smoothness and flow time.

The following five sub-sections in turn review the literature for each of the five BTOSC decision types. 
Table 2. Summary of decision problems in BTO-SC with dyadic/network relations among multiple parties

\begin{tabular}{|c|c|c|c|c|c|c|c|c|}
\hline Decision Type & Interface & Description & Objectives $^{*}$ & $\begin{array}{c}\mathrm{MOO} / \\
\text { non-MOO }\end{array}$ & $\begin{array}{l}\text { Key Decision } \\
\text { Variables }\end{array}$ & Technique & $\begin{array}{l}\text { Data Type / } \\
\text { Industry }\end{array}$ & Reference \\
\hline \multirow{7}{*}{$\begin{array}{l}\text { Order } \\
\text { Promising } \\
\text { ( Due-date } \\
\text { assignment) }\end{array}$} & \multirow[t]{2}{*}{$\begin{array}{l}\text { Supplier- } \\
\text { Manufacturer- } \\
\text { Customer }\end{array}$} & $\begin{array}{l}\text { A model to provide an order-promising } \\
\text { and fulfilment solution for a batch of } \\
\text { orders within a batching interval. }\end{array}$ & $\begin{array}{l}\text { Maximize overall profit } \\
\text { (M) }\end{array}$ & non-MOO & $\begin{array}{l}\text { Batching Interval } \\
\text { Size; } \\
\text { Quantity } \\
\text { promised to be } \\
\text { delivered by } \\
\text { requested } \\
\text { delivery time; } \\
\end{array}$ & MIP & $\begin{array}{l}\text { Maxtor (Hard } \\
\text { Disk Drive } \\
\text { Producer) }\end{array}$ & $\begin{array}{l}\text { Chen et al. } \\
\quad \text { (2002) }\end{array}$ \\
\hline & & $\begin{array}{l}\text { The model determines which order to } \\
\text { accept and specifies the corresponding } \\
\text { delivery time and delivery quantity. }\end{array}$ & $\begin{array}{l}\text { Maximize overall profit } \\
\text { (M) }\end{array}$ & non-MOO & $\begin{array}{l}\text { Deliver Time; } \\
\text { Delivery } \\
\text { Quantity; }\end{array}$ & MIP & Toshiba Japan PC & $\begin{array}{l}\text { Chen et al. } \\
\quad(2001)\end{array}$ \\
\hline & $\begin{array}{l}\text { Manufacturer- } \\
\text { Distributer- } \\
\text { Customer } \\
\end{array}$ & $\begin{array}{l}\text { A network flow problem which allows } \\
\text { customers to negotiate due dates and } \\
\text { price with the manufacturer. }\end{array}$ & $\begin{array}{l}\text { Minimize overall } \\
\text { ordering cost (M) }\end{array}$ & non-MOO & $\begin{array}{l}\text { Purchase Cost; } \\
\text { Due-date; }\end{array}$ & LP & Synthetic & $\begin{array}{l}\text { Venkatadria } e t \\
\text { al. }(2006)\end{array}$ \\
\hline & \multirow{4}{*}{$\begin{array}{l}\text { Manufacturer- } \\
\text { Customer }\end{array}$} & $\begin{array}{l}\text { An assignment problem of customers to } \\
\text { finished goods. The model generates } \\
\text { available to promise schedules (Order } \\
\text { Sequence). }\end{array}$ & $\begin{array}{l}\text { Maximize overall profit } \\
\text { (M) }\end{array}$ & non-MOO & $\begin{array}{l}\text { Order Quantities; } \\
\text { Due-dates; }\end{array}$ & MIP & Conceptual (N/A) & Pibernik (2005) \\
\hline & & $\begin{array}{l}\text { The model determines delivery dates by } \\
\text { considering available resources relative to } \\
\text { a batch of orders. }\end{array}$ & $\begin{array}{c}\text { Minimize due date } \\
\text { violation }(\mathrm{S}) ; \\
\text { Minimize inventory } \\
\text { holding cost }(\mathrm{M}) ; \\
\text { Minimize day-to-day } \\
\text { production smoothness } \\
\text { measure }(\mathrm{O}) \\
\end{array}$ & MOO & $\begin{array}{l}\text { Due date; } \\
\text { Quantity } \\
\text { Produced in each } \\
\text { Factory; }\end{array}$ & MIP & Toshiba Japan & $\begin{array}{l}\text { Zhao et al. } \\
\quad(2005)\end{array}$ \\
\hline & & $\begin{array}{l}\text { The model estimates the portion of lead } \\
\text { time due to queuing for resources by } \\
\text { considering time-phased resource } \\
\text { availability. }\end{array}$ & $\begin{array}{l}\text { Minimize median and } \\
\text { standard deviation of } \\
\text { absolute flow time }(\mathrm{O}) \\
\text { and lateness error }(\mathrm{S}) \\
\end{array}$ & non-MOO & $\begin{array}{l}\text { Flow Time; } \\
\text { Lateness; }\end{array}$ & Simulation & Synthetic & $\begin{array}{l}\text { Moses et al. } \\
\quad(2004)\end{array}$ \\
\hline & & $\begin{array}{l}\text { The model determines the optimal due } \\
\text { dates by considering the manufacturer's } \\
\text { resource availability when customer can } \\
\text { request earlier due dates by paying a } \\
\text { higher price to cover the extra } \\
\text { manufacturing cost. }\end{array}$ & $\begin{array}{l}\text { Minimize completion } \\
\text { time }(\mathrm{S})\end{array}$ & non-MOO & $\begin{array}{l}\text { Due-dates; } \\
\text { Cost; }\end{array}$ & $\begin{array}{l}\text { Fuzzy } \\
\text { Logic }\end{array}$ & $\begin{array}{c}\text { Furniture } \\
\text { Manufacturer }\end{array}$ & $\begin{array}{l}\text { Wang et al. } \\
\quad(1998)\end{array}$ \\
\hline
\end{tabular}


Table 2. Continued from previous page

\begin{tabular}{|c|c|c|c|c|c|c|c|c|}
\hline Decision Type & Interface & Description & Objectives* $^{*}$ & $\begin{array}{c}\mathrm{MOO} / \\
\text { non-MOO }\end{array}$ & $\begin{array}{l}\text { Key Decision } \\
\text { Variables }\end{array}$ & Technique & $\begin{array}{l}\text { Data Type / } \\
\text { Industry }\end{array}$ & Reference \\
\hline \multirow{2}{*}{$\begin{array}{l}\text { Order } \\
\text { Promising } \\
\text { ( Due-date } \\
\text { assignment) } \\
\text { continues }\end{array}$} & \multirow{2}{*}{$\begin{array}{l}\text { Manufacturer- } \\
\text { Customer } \\
\text { Continued }\end{array}$} & $\begin{array}{l}\text { The model quotes due dates for demand } \\
\text { orders with requested due dates. }\end{array}$ & $\begin{array}{l}\text { Minimize total cost } \\
\text { (tardiness + inventory } \\
\text { cost })(\mathrm{M}) \\
\end{array}$ & non-MOO & Due Dates; & $\begin{array}{l}\text { Approxima } \\
\text { tion }\end{array}$ & Synthetic & $\begin{array}{l}\text { Hegedus and } \\
\text { Hopp (2001) }\end{array}$ \\
\hline & & $\begin{array}{l}\text { The model chooses the biding decision } \\
\text { that estimates the contract price-due date } \\
\text { pairs. }\end{array}$ & $\begin{array}{l}\text { Maximize expected } \\
\text { profit }(\mathrm{M})\end{array}$ & non-MOO & $\begin{array}{l}\text { Price; } \\
\text { Delivery date; } \\
\text { Cost; }\end{array}$ & $\begin{array}{l}\text { Approxima } \\
\text { tion }\end{array}$ & Synthetic & $\begin{array}{c}\text { Easton and } \\
\text { Moodie (1999) }\end{array}$ \\
\hline \multirow{2}{*}{$\begin{array}{c}\text { Procurement } \\
\text { and Inventory } \\
\text { Control } \\
\text { (Resource } \\
\text { Planning) }\end{array}$} & \multirow{2}{*}{$\begin{array}{l}\text { Supplier- } \\
\text { Manufacturer }\end{array}$} & $\begin{array}{l}\text { The model determines optimum } \\
\text { sequences and presents tradeoffs between } \\
\text { level of customization and inventory level } \\
\text { of supplier. }\end{array}$ & $\begin{array}{l}\text { Minimize maximum } \\
\text { amount of inventory } \\
\text { that prevents stockout } \\
\text { (S) }\end{array}$ & non-MOO & $\begin{array}{l}\text { Inventory Level; } \\
\text { No. of Variant in } \\
\text { Order; }\end{array}$ & Simulation & Automotive & Aigbedo (2007) \\
\hline & & $\begin{array}{l}\text { The model compares pricing and } \\
\text { delivery-frequency decisions to achieve } \\
\text { the optimum performance for both } \\
\text { parties. }\end{array}$ & $\begin{array}{l}\text { Minimize overall cost } \\
\text { (M) }\end{array}$ & non-MOO & $\begin{array}{c}\text { Delivery } \\
\text { Frequencies; } \\
\text { Delivery } \\
\text { Quantities; } \\
\text { Price; } \\
\end{array}$ & $\begin{array}{l}\text { Game } \\
\text { Theory }\end{array}$ & Synthetic & Ha et al. (2003) \\
\hline \multirow{4}{*}{$\begin{array}{l}\text { Production } \\
\text { Scheduling } \\
\text { (Production } \\
\text { Planning) }\end{array}$} & \multirow{3}{*}{$\begin{array}{l}\text { Manufacturer- } \\
\text { Customer }\end{array}$} & $\begin{array}{l}\text { The model ensures that orders for MTO } \\
\text { items are fulfilled within a lead time with } \\
\text { a specified probability. }\end{array}$ & $\begin{array}{l}\text { Minimize inventory } \\
\text { costs of MTS items (M) }\end{array}$ & non-MOO & $\begin{array}{l}\text { Lead Time; } \\
\text { Batch size; }\end{array}$ & MIP & Synthetic & $\begin{array}{l}\text { Rajagopalan } \\
\text { (2002) }\end{array}$ \\
\hline & & $\begin{array}{l}\text { Planning and scheduling in a multi- } \\
\text { product flow-shop production to meet the } \\
\text { quantity and delivery date of customer } \\
\text { orders. }\end{array}$ & $\begin{array}{l}\text { Minimizing } \\
\text { unproductive } \\
\text { production time }(\mathrm{O})\end{array}$ & non-MOO & $\begin{array}{l}\text { Production Cost; } \\
\text { Production } \\
\text { Sequence; }\end{array}$ & $\begin{array}{l}\text { MIP } \\
\text { LP }\end{array}$ & Pharmaceutical & $\begin{array}{l}\text { Stefansson et al. } \\
\quad \text { (2009) }\end{array}$ \\
\hline & & $\begin{array}{l}\text { A bidding model with multiple customer } \\
\text { segments. }\end{array}$ & $\begin{array}{l}\text { Maximize expected } \\
\text { marginal revenue }(\mathrm{M})\end{array}$ & non-MOO & $\begin{array}{c}\text { Bid Price; } \\
\text { Promised Due } \\
\text { Dates; } \\
\text { Sequencing } \\
\text { Position for each } \\
\text { Job; } \\
\end{array}$ & $\begin{array}{l}\text { Simplified } \\
\text { Pattern } \\
\text { Search }\end{array}$ & Synthetic & $\begin{array}{l}\text { Watanapa and } \\
\text { Techanitisawad } \\
\text { (2005) }\end{array}$ \\
\hline & $\begin{array}{l}\text { Manufacturer- } \\
\text { Distributer }\end{array}$ & $\begin{array}{l}\text { The model presents tradeoffs between the } \\
\text { manufacturer's desires for scheduling } \\
\text { flexibility versus the vendors' need for } \\
\text { schedule stability. }\end{array}$ & $\begin{array}{l}\text { Minimize Schedule } \\
\text { Cost }(\mathrm{M}) \\
\text { Minimize Schedule } \\
\text { Instability }(\mathrm{O})\end{array}$ & MOO & $\begin{array}{l}\text { Vendor's Cost } \\
\text { Manufacturing } \\
\text { Cost; } \\
\text { Instability; }\end{array}$ & Simulation & Synthetic & $\begin{array}{l}\text { Sahin } e t \\
\text { al. }(2008)\end{array}$ \\
\hline
\end{tabular}


Table 2. Continued from previous page

\begin{tabular}{|c|c|c|c|c|c|c|c|c|}
\hline Decision Type & Interface & Description & Objectives ${ }^{*}$ & $\begin{array}{c}\mathrm{MOO} / \\
\text { non-MOO }\end{array}$ & $\begin{array}{l}\text { Key Decision } \\
\text { Variables }\end{array}$ & Technique & $\begin{array}{l}\text { Data Type / } \\
\text { Industry }\end{array}$ & Reference \\
\hline \multirow[b]{2}{*}{$\begin{array}{l}\text { Network } \\
\text { Design }\end{array}$} & \multirow{2}{*}{$\begin{array}{l}\text { Supplier- } \\
\text { Manufacturer- } \\
\text { Distributer- } \\
\text { Customer }\end{array}$} & $\begin{array}{l}\text { The model proposes a capacity and } \\
\text { resource plan by maintaining the desired } \\
\text { customer service level. }\end{array}$ & $\begin{array}{l}\text { Minimize the overall } \\
\text { operating cost }(\mathrm{M})\end{array}$ & non-MOO & $\begin{array}{c}\text { Inventory Level; } \\
\text { Assembled } \\
\text { Volume in } \\
\text { Regular Time; } \\
\text { Assembled } \\
\text { Volume in } \\
\text { Overtime; } \\
\end{array}$ & MIFP & Synthetic & $\begin{array}{l}\text { Demirli and } \\
\text { Yimer (2008) }\end{array}$ \\
\hline & & $\begin{array}{l}\text { The model chooses the location of plants } \\
\text { and distribution centres and determines } \\
\text { the inventory policy and control } \\
\text { parameters associated with it. }\end{array}$ & $\begin{array}{l}\text { Minimize total average } \\
\text { cost per each filled } \\
\text { demand }(\mathrm{M}) \\
\text { Maximize demand fill } \\
\text { rate }(\mathrm{S})\end{array}$ & MOO & $\begin{array}{c}\text { Open or Close } \\
\text { Decision; } \\
\text { Production Order } \\
\text { Assignment } \\
\text { weight; } \\
\text { Order Quantity } \\
\text { (Q); } \\
\text { Reorder Point } \\
\text { (R); } \\
\end{array}$ & $\begin{array}{l}\text { MOGA } \\
\text { Simulation }\end{array}$ & $\begin{array}{l}\text { Automotive and } \\
\text { Textile }\end{array}$ & $\begin{array}{l}\text { Ding et al. } \\
(2006,2009)\end{array}$ \\
\hline \multirow{4}{*}{$\begin{array}{c}\text { Product } \\
\text { Design } \\
\text { (Configuration } \\
\text { Optimization) }\end{array}$} & $\begin{array}{l}\text { Supplier- } \\
\text { Manufacturer }\end{array}$ & $\begin{array}{l}\text { The model to identify the product family } \\
\text { and its relevant supply chain. }\end{array}$ & $\begin{array}{l}\text { Minimize operation } \\
\text { costs (M) }\end{array}$ & non-MOO & $\begin{array}{c}\text { Cost; } \\
\text { Bill-of-materials; } \\
\text { Shipping } \\
\text { Channel; } \\
\end{array}$ & MILP & Automotive & $\begin{array}{l}\text { Lamothe et al. } \\
\qquad(2006)\end{array}$ \\
\hline & \multirow{3}{*}{$\begin{array}{l}\text { Manufacturer- } \\
\text { Customer }\end{array}$} & $\begin{array}{l}\text { A product configuration optimization } \\
\text { model to deliver customized products at } \\
\text { the lowest cost. }\end{array}$ & $\begin{array}{l}\text { Maximize the ratio } \\
\text { between customer- } \\
\text { perceived utility and } \\
\text { cost }(\mathrm{M}, \mathrm{S}) \\
\end{array}$ & non-MOO & $\begin{array}{l}\text { Utilities; } \\
\text { Cost; }\end{array}$ & MOGA & $\begin{array}{l}\text { Notebook } \\
\text { Producer }\end{array}$ & $\begin{array}{l}\text { Zhou et al. } \\
\quad(2009)\end{array}$ \\
\hline & & $\begin{array}{l}\text { The model jointly selects the optimal } \\
\text { policies for return policy and modularity } \\
\text { levels. }\end{array}$ & $\begin{array}{l}\text { Maximize expected } \\
\text { profit }(\mathrm{M})\end{array}$ & non-MOO & $\begin{array}{l}\text { Return Quantity; } \\
\text { Cost; }\end{array}$ & $\begin{array}{l}\text { Approxima } \\
\text { tion }\end{array}$ & Synthetic & $\begin{array}{l}\text { Mukhopadhyay } \\
\text { and Setoputro } \\
\text { (2005) }\end{array}$ \\
\hline & & $\begin{array}{l}\text { A framework for finding optimal modules } \\
\text { in a delayed product differentiation } \\
\text { scenario. }\end{array}$ & $\begin{array}{l}\text { Minimize mean no. of } \\
\text { assembly operations } \\
(\mathrm{O}) \text {; } \\
\text { Minimize expected } \\
\text { pre-assembly cost }(\mathrm{M}) \text {; }\end{array}$ & MOO & $\begin{array}{l}\text { Products } \\
\text { Attributes; } \\
\text { No. of Moduls; }\end{array}$ & MOGA & $\begin{array}{c}\text { Truck } \\
\text { Manufacturer }\end{array}$ & $\begin{array}{c}\text { Song and } \\
\text { Kusiak (2010) }\end{array}$ \\
\hline
\end{tabular}

* Objective codes: M (Money-based); S (Service-based); O (Operation-based) 


\subsection{Order promising decisions}

Order promising or due-date assignment is one of the most important customer service decisions (Moses et al. 2004). With increased standards and expectations involving due date quoting within a supply chain, organizations require sophisticated approaches to execute order promising and fulfilment, especially in today's high-mix low-volume production environment (Zhao et al., 2005). Build-to-order firms have few standard products and volatile, difficult-to-predict demand (Easton and Moodie, 1999) and do not build an inventory of standard products, thus they generally lack the ability to provide promised completion dates to customers that are achievable, tight and computed in real time for dynamic order arrivals (Moses et al. 2004). The basic decision faced by a supplier or manufacturer is whether to commit to a requested due date for a customer order. Ideally, suppliers or manufacturers would like to quote (be able to commit to) as many orders as possible on the customers' requested due dates to gain more profit. Order promising models and systems must directly link customer orders with various forms of available resources, including both material and production capacity. A variety of constraints, such as raw material availability, production capacity, material compatibility and customer preferences are considered by authors who have developed different models for quoting due dates in BTO environments. As can be seen in Table 2, both simulation and analytical approaches have been used in the literature to determine the optimum due dates which maximize overall firms' profit while considering these aforementioned constraints. Mixed Integer Programming (MIP) has commonly been used to solve the problem of due date assignment.

Wang et al. (1998) address joint due date assignment and production planning under fuzzy assumptions. They develop a bargainer tool that can be used at the customermanufacturer interface to decide on delivery due date and cost for a make-to-order (MTO) manufacturing system. This tool works with 'sales management' and 'production planning' modules of a manufacturing resource planning (MRP-II) system. They propose a three phase solution approach assuming for a number of fixed orders at a given time. After initializing the system with near optimal due dates from the manufacturer's point of view, customers may start bargaining for shorter delivery lead times one at a time. In the bargaining process, alternative due dates are offered to the customers at the expense of extra cost required to pay for delayed delivery of 
already agreed due dates with other customers. The solution tool is tested on a smallscale scenario where six orders were available for an MTO manufacturer. The authors conclude that the proposed solution approach requires fundamental improvement so it can be used for dynamic daily orders from several customers at the same time. As such, this approach would seem not to be suitable for BTO-SC where theoretically thousands of customers can interact with manufacturers on a daily basis. Moreover, the current constraint of dealing with customers one-by-one needs to be addressed so that it can be used for global supply chains where customers interact with the sales management module virtually independently of each other, and often simultaneously.

Easton and Moodie (1999) analyze the problem of competitive biding with contingent orders for a static, single resource MTO firm. They use a two-dimensional logit model, based on contract price and lead time, to estimate the probability of a successful bid. Their model focuses on establishing the price and lead time for a single job, but does not consider the dynamic arrivals of jobs in real-time situations. Another limitation of the model is that they use an enumerative solution procedure which can not be applied in large scale problems with multiple customers and hundreds of contingent orders. More efficient search techniques like heuristic-based search procedures are needed to establish bid prices and lead times for real life problems. Hegedus and Hopp (2001) propose a model for quoting due dates in a MTO environment where customers request due dates. Their model incorporates a two-stage production system that describes inventory cost, fill rate, and service level issues. They simplify the manufacturing phase of the production process into a news vendor-like problem formulation and obtain a simple optimal policy for both single and multiple demand order problems.

Chen et al. (2001a, 2002) propose a model to provide a delivery date and committed quantity for each order requested by a customer. Their model considers multiple products and a flexible bill of materials which allows the customer to configure their products at both the material type level and supplier level. They also investigate the sensitivity of supply chain performance to changes in certain parameters such as batching intervals size and customer order flexibility with simulation experiments. Moses et al. (2004) present a model for real-time promising of order due dates that is applicable to discrete BTO environments facing dynamic order arrivals. Their 
approach estimates the portion of lead time due to queuing for resources by considering time-phased resource availability.

Pibernik (2005) proposes a theoretical framework for the development of models and algorithms supporting order quantity and due date quoting. Pibernik classifies Advanced Available-to-Promise (AATP) techniques, different tools and methods to enhance the responsiveness of order promising and reliability of order fulfilment, into eight generic AATP methods. In this classification three characteristics are considered: 1- availability level (finished goods or supply chain resource), 2operating mode (real-time or batch), and 3- Interaction with manufacturing resource planning (active or passive). Venkatadri et al. (2006), most recently present an optimization-based decision support system (DSS) for quoting due dates and prices in an eCommerce context. Their proposed DSS addresses four questions about negotiations between the buyer and the supplier on the quantity, marginal cost, and lead time of each product unit.

\subsection{Procurement and inventory control decisions}

In a typical supply chain raw materials are procured and stored in buffer inventory while finished items are produced in manufacturing centres, stored in internal finished products' inventory or stored in intermediate warehouses and then shipped to buyers or distribution centres (Diponegoro and Saker, 2006). Adopting a BTO strategy would allow firms to effectively customize their products to a greater degree towards meeting specific customer requirements, and it could also effect large cost savings by reducing raw material, work-in-process (WIP) and finished good inventories while improving production flexibility (Demirli and Yimer, 2008). Managing inventory levels for raw materials, WIP, and finished goods at different stock points is a complex task involving trade-off analysis between inventory cost, lead times and customer service level. Although carrying inventories is essential to enhance the customer service level and cut shortage costs, excess inventories are usually barriers to achieving high responsiveness and minimum operating costs (Demirli and Yimer, 2008).

Two research papers were found that deal with procurement and inventory issues in BTO-SC. Ha et al. (2003) examine the role of delivery frequency in supplier 
competition. They propose several models with different assumptions on how pricing and delivery frequency decisions are made within the supply chain. They show that delivery frequency can be a source of competitive advantage. Aigbedo (2007) propose a framework to examine the effect of mass customisation (MC) on inventory of parts used in a just-in-time (JIT) manufacturing environment. Aigbedo investigates the extent to which customization impacts the average inventory of each variant that should be maintained to meet the Original Equipment Manufacturer (OEM)'s need. By using computer simulation Aigbedo finds that mass customization tends to increase the average amount of inventory of the parts variants needed to be held constantly to prevent stock outs.

\subsection{Production planning decisions}

Production planning and scheduling is an established and extensively studied field within the supply chain management domain and has received great attention and interest from both practitioners and academics. Regardless of adopting BTO or MTS strategies, all manufacturing firms make decisions on production planning and scheduling on a regular basis. In an MTO environment, at each arrival of customer, the firm needs to dynamically determine prospective due date and price quotation based on the streamlined information from the capacity planning and production scheduling (Kingsman et al., 1996). In practice, the manufacturer tries to optimize the production schedule and then release purchase orders one at a time to vendors. However, the manufacturer may transfer operational inefficiencies to upstream suppliers in an attempt to minimize their cost, thereby causing sub-optimal system performance (Lee et al., 1997). There is a substantial literature on planning and scheduling techniques, particularly, on resource(s) allocation and sequencing.

Rajagopalan (2002) develop a nonlinear, integer programming model to analyze the impact of various problem parameters on MTO versus MTS decisions, and finds that the average number of setups of an item selected for MTS production is always less than half the average number of setups of the item if it were to be made to order. Watanapa and Techanitisawad (2005) propose a bidding model with multiple customer segments classified based on parameters of willingness to pay, sensitivity to short delivery time, quality level requirement, and intensity of competition to optimize the biding price and due date for each incoming order. They apply a Simplified 
Pattern Search (SPS) method to efficiently find optimal price and due dates with the help of resequencing and utilization of production capacity. Using simulation, they show that the model could increase the marginal revenue for the bidding system significantly.

Sahin et al. (2008) present a framework for jointly analyzing the impact of Master Production Schedule (MPS) and Advanced Order Commitment (AOC) in two-stage supply chains. Using computer simulation they evaluate the impacts of environmental and MPS design factors on optimal policy design by measuring schedule cost and stability factors. They find that the vendor's order-size flexibility is the major factor impacting system performance. They conclude that the manufacturer's optimal MPS policy is often inefficient for the vendor which results in total costs being significantly greater than the optimal system policy. Stefansson et al. (2009) introduce a modelling approach for creating robust production plans and schedules under uncertain and varied demand conditions. They propose a multi-scale hierarchically structured algorithm with three levels of decisions. At each level they apply several optimization methods to provide support for the relevant decision. They prove that their approach was capable of obtaining a realistic and profitable solution within acceptable computational times by testing it with industrial data from an MTO pharmaceutical plant.

\subsection{Network design decisions}

Production-distribution design has significant impacts on a supply chain's long-term performance. The number of plants and/or distribution centres as well as their geographical locations must be determined at the network design phase. This leads to many complex decision making processes and trade-off analysis regarding conflicting criteria, for example costs and customer service level. Ding et al. (2006) state that the design of enterprise networks requires the determination of:

- the number, location, capacity, and type of manufacturing plants, warehouses, and distribution centres to be used;

- the set of suppliers to be engaged;

- the transportation modes to be used; and 
- the quantity of raw materials and finished products to purchase, produce, store and transport among suppliers, plants, warehouses, distribution centres, and customers.

They develop a tool box - "ONE" - for supply chain network simulation and optimization. One tool is a decision making tool that can be used on supplier selection, transportation links allocation and central warehouse inventory control. Multi Objective Genetic Algorithm (MOGA) is adopted in ONE to perform stochastic search for solutions regarding network structure as well as operational parameters, for example inventory control parameters and transportation allocation parameters.

Demirli and Yimer (2008) develop a fuzzy mathematical programming model of integrated production-distribution planning for a multi-echelon BTO furniture supply chain. Their production subsystem includes raw material suppliers, component fabricators and product assemblers and their distribution subsystem consists of finished products warehouses, intermediate distribution centres, retailers and end-user customers. The objectives of their model include minimizing the most possible imprecise total cost, maximizing the possibility of obtaining a lower total cost and minimizing the risk of a higher total cost. By introducing a factor for decision satisfaction level they reduce the Multi Objective Linear Programming (MOLP) problem to an equivalent single goal satisfying the linear programming problem. The demonstrative example they present in their paper supports the applicability of the proposed model.

\subsection{Product design decisions}

A BTO strategy gives firms the opportunity to customize the product to the requirements of customers. Internet-based configuration systems allow customers to configure products by selecting desired features. However, maintaining a large number of different product configurations increases production complexity and can extend delivery lead time (Da Cunha et al., 2007). In general, the most research literature related to customer-driven product configuration optimization is focused on modular product design or product family design. The concept of developing product families and modular architectures are of interest to manufacturing companies in the quest to meet diverse customer requirements while maintaining an economy of scale (Farrell and Simpson, 2003). Different products can be easily obtained through 
different combinations of modules. Chakravarty and Balakrishnan (2001) argue that modular design of product is one way to achieve higher product performance without increasing manufacturing cost in a disproportionate manner. When designing a new product family, a consistent approach is necessary to quickly define a set of product variants and their relevant supply chain, in order to guarantee the customer satisfaction and to minimize the total operating cost of the global supply chain (Lamothe et al., 2006).

Mukhopadhyay and Setoputro (2005) develop a model to yield the optimal policies regarding return and the design modularity for BTO products. Their model analyzes the effect of modularity and return policy on the product demand, amount returned, and profit. They propose design modularity as a means of achieving generous and economically viable return policy for BTO products. Lamothe et al. (2006), propose a design approach that allows defining simultaneously a product family and its supply chain while facing a customer demand with a large diversity. They present a Mixed Integer Linear Programming (MILP) model to identify the product family and its relevant supply chain, while optimizing a cost function. Their model analyzes three kinds of diversity, namely Market diversity, Product diversity and Supply chain layout diversity.

Zhou et al. (2009) propose an optimization method for product configuration considering both customer and designer's viewpoints for Assemble-to-Order (ATO) manufacturing enterprises. They employ a utility function to model and measure customer preference. Subsequently they formulated a mathematical model with the objective of maximizing the utility per cost. They use Genetic Algorithm (GA) to solve the combinatorial optimization problem of product configuration. Song and Kusiak (2010) present a general framework of mining Pareto-optimal modules from historical sales data. They consider two different objectives for determining optimal product modules as: minimizing mean number of assembly operations and minimizing the expected pre-assembly cost. They apply an evolutionary computation algorithm to select product modules based on multiobjective criteria. 


\section{Available software packages}

Numerous supply chain solution tools are readily available to companies and the SCM software industry is gaining increased attention as companies try to maximize return on investment and gain a competitive edge in the market. However, few vendors provide optimization tools and solutions suitable for BTO supply chains. For example, in 'order promising' decision problems, the SCM system needs to take a customer request for a product configuration and provide an accurate delivery date for that request. A comprehensive solution should then provide trade-off analysis on delivery date, product option content and price for both the firm and the prospective customer. The software should be capable to promise accurate due dates by directly scheduling the product against inventory, the sequence and master schedule and the production and distribution plan.

Based on an initial survey on the internet and using other public resources, we identified five SCM software packages that are capable of providing decision support in BTO environments. Table 3 outlines these packages and the decision interfaces for which they can be used. It also identifies the corresponding decision type (column 3 Solution) and it is evident that the decision types tackled by these packages closely correspond to the five decision types found in the BTO-SC optimization literature. However, as the description of objectives (column 4) demonstrates, in most cases, a single objective is considered for the optimization problem at hand. Some of the packages seem to be capable of simulation based scenario analysis taking into account alternative solutions defined by the users. As a primary observation, it can be concluded that the theory of MOO has not been applied and integrated to its full potential in the current packages in providing the complete or approximations of Pareto optimal front. It should however be noted, that due to the lack of detailed information about the underlying algorithms used in these commercial packages, we were not able to verify this in more detail. 
Table 3. The elements of major software packages for decision making in BTO environment

\begin{tabular}{|c|c|c|c|c|}
\hline Package & Interface & Solution & Description of objectives & Key decision variables \\
\hline \multirow{4}{*}{$\begin{array}{l}\text { Oracle } \\
\text { E-Business } \\
\text { Suite SCM }\end{array}$} & Manufacturer & Production Scheduling & $\begin{array}{l}\text { Optimizes the usage of critical resources and determines the schedule that } \\
\text { best meets a firm's objectives. Enables to compare schedules with } \\
\text { different delivery performance and cost. }\end{array}$ & $\begin{array}{l}\text { Overtime working cost; } \\
\text { delivery performance }\end{array}$ \\
\hline & $\begin{array}{l}\text { Supplier- } \\
\text { Manufacturer- } \\
\text { Distributer- } \\
\text { Customer }\end{array}$ & $\begin{array}{l}\text { Strategic Network } \\
\text { Optimizer }\end{array}$ & $\begin{array}{l}\text { Designs the entire supply chain and determines the best possible network } \\
\text { configuration based on supply chain's costs and constraints. }\end{array}$ & $\begin{array}{l}\text { Transportation cost; } \\
\text { cash flow; working capital; } \\
\text { production cost }\end{array}$ \\
\hline & $\begin{array}{l}\text { Supplier- } \\
\text { Manufacturer- } \\
\text { Distributer } \\
\end{array}$ & Inventory Optimization & $\begin{array}{l}\text { Enables to balance revenue, cost, customer service levels and inventory } \\
\text { budgets and determine inventory postponement strategy. Determines how } \\
\text { much and where to hold inventory in different stages of production. }\end{array}$ & $\begin{array}{l}\text { Customer service level; } \\
\text { inventory level; } \\
\text { inventory cost }\end{array}$ \\
\hline & $\begin{array}{l}\text { Supplier- } \\
\text { Manufacturer- } \\
\text { Distributer- } \\
\text { Customer } \\
\end{array}$ & Global Order Promising & $\begin{array}{l}\text { Calculates order fulfilment dates considering the allocated material and } \\
\text { capacity at each level of the supply chain. Determines the best location } \\
\text { based on the product and order request date. }\end{array}$ & Due dates \\
\hline \multirow{3}{*}{ SAP SCM } & $\begin{array}{l}\text { Supplier- } \\
\text { Manufacturer }\end{array}$ & $\begin{array}{c}\text { Material Requirements } \\
\text { Planning-based Detailed } \\
\text { Scheduling }\end{array}$ & $\begin{array}{l}\text { Create feasible production plans across different production locations to } \\
\text { fulfil demand to the schedule. }\end{array}$ & Order sequence \\
\hline & Manufacturer & $\begin{array}{l}\text { Production Planning and } \\
\text { Detailed Scheduling }\end{array}$ & $\begin{array}{l}\text { Generates optimized schedules for machine, labour, and overall capacity } \\
\text { utilization. }\end{array}$ & $\begin{array}{l}\text { Due date; } \\
\text { production sequence }\end{array}$ \\
\hline & $\begin{array}{l}\text { Manufacturer - } \\
\text { Customer }\end{array}$ & Sales Order Processing & $\begin{array}{l}\text { Determines specific delivery dates for different product configuration and } \\
\text { quantity }\end{array}$ & $\begin{array}{l}\text { Order quantity; } \\
\text { delivery date }\end{array}$ \\
\hline $\mathrm{i} 2$ & $\begin{array}{c}\text { Manufacturer- } \\
\text { Distributer- } \\
\text { Customer } \\
\end{array}$ & Order Promising & $\begin{array}{l}\text { Provides alternatives and tradeoffs for a product configuration and } \\
\text { delivery date for the distributor or customer. }\end{array}$ & $\begin{array}{l}\text { Delivery date; } \\
\text { product option content; } \\
\text { price }\end{array}$ \\
\hline IBM & $\begin{array}{l}\text { Supplier- } \\
\text { Manufacturer- } \\
\text { Distributer- } \\
\text { Customer }\end{array}$ & $\begin{array}{c}\text { General Business } \\
\text { Simulation Environment }\end{array}$ & $\begin{array}{l}\text { Chooses the location of plants and distribution centres and determines the } \\
\text { inventory policy. }\end{array}$ & $\begin{array}{l}\text { Open or close decision; } \\
\text { order quantity; reorder point }\end{array}$ \\
\hline LogicTools & $\begin{array}{l}\text { Manufacturer- } \\
\text { Distributer }\end{array}$ & ILOG Inventory Analyst & $\begin{array}{l}\text { Determines the right inventory policies and strategic positioning of } \\
\text { inventory to reduce inventory while improving customer service level. }\end{array}$ & $\begin{array}{l}\text { Customer service level; } \\
\text { inventory level; } \\
\text { inventory cost }\end{array}$ \\
\hline
\end{tabular}




\section{Discussion and future directions}

After examining the existing body of work in the area of MOO for BTO-SC in previous sections, here we discuss our major observations and suggestions of directions for future research.

As shown in Figure 4, among the five major decision types, order promising has received the largest attention in the literature followed by production planning and product design, then network design and resource planning. These statistics reflect the importance of methodologies where customer input is crucial in planning supply chain activities in the areas of order promising and product (or configuration) design.

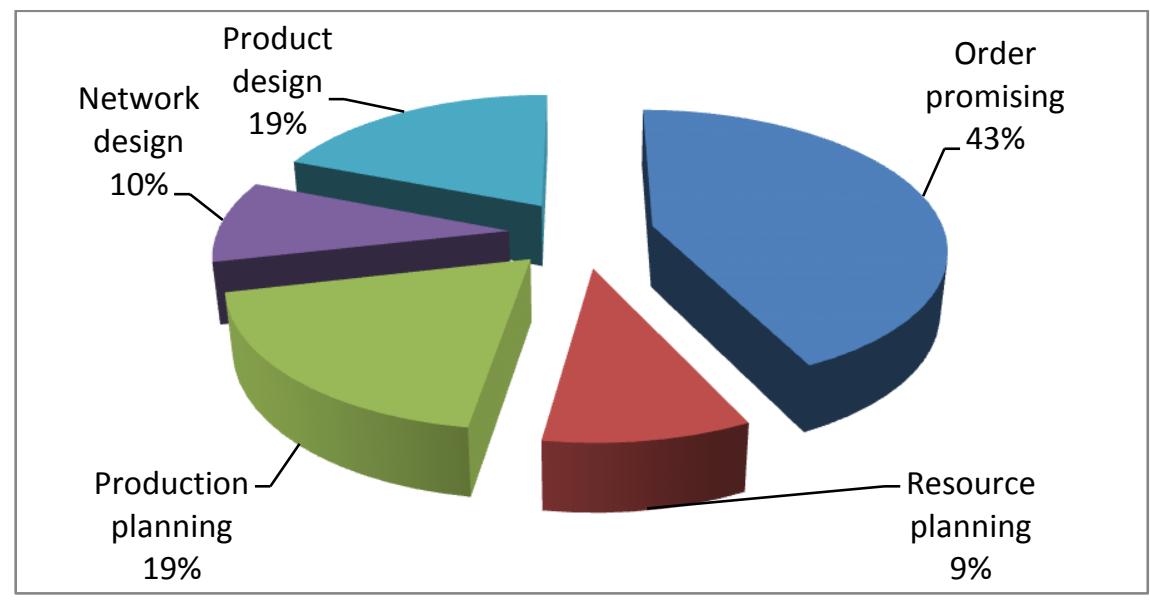

Figure 4. Percentage of the articles addressing problems in the five decision type areas

As shown in table 2, only 4 of the BTO-SC optimization contributions that we identified were already using a MOO technique while the other 17 papers did not use MOO techniques. These papers (non-MOOs) are therefore candidates for the expansion or reformulation of their objective functions to facilitate more multifaceted decision support through future research.

An important factor in the design and development of different optimization models for each paper is the parties involved in the decision-making for each problem. Thus, papers can be categorized based on the different interfaces (decision points) in a supply chain. The major decision makers in a typical BTO-SC are suppliers, manufacturers, distributors, and customers. Figure 5 shows the various combinations 
of decision-making parties (i.e. the interfaces) that we observed in the reviewed BTOSC literature, and shows the number of papers reviewed for each interface.

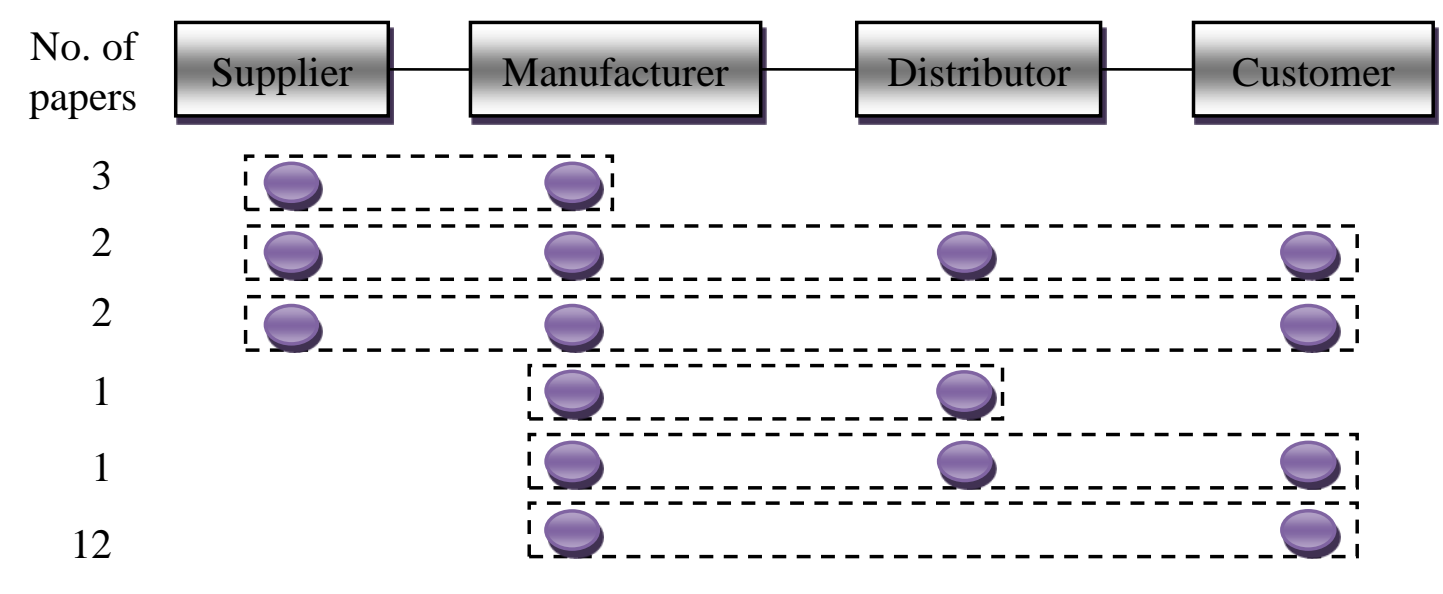

Figure 5. Number of papers in each interface

As figure 5 illustrates, more than half of the previous publications $(57 \%)$ have been focused on the manufacturer-customer interface (12 papers). It appears that it is primarily for simplification purposes that those studies tend to analyze a two-stage BTO supply chain consisting of a manufacturer with different customers. Not surprisingly, we also observe that the manufacturer has been a focal party in all of the studies. Given the increasing proportion of economic activity in the West centred on the service sector, one potential avenue for further research would be development of decision supports for interfaces not involving manufacturers, in particular between customer and service providers who provide customized services. The distributor link was the least represented decision party in the BTO-SC optimization literature. Another salient finding, in reference back to figure5, is the absence of logistics providers in the current BTO-SC literature. With the increasing separation of logistics service provision from the manufacturer and the rising cost of transportation in general, it would appear that significant opportunities exist to develop MOO decision support for the interfaces of manufacturer-logistic provider and distributorogistics provider.

As is illustrated in Figure 6, the money-based objectives are dominant followed by service-based and operation-based criteria. Applications and developments centred 
on money-based objectives are expected to be as important in the future. At the same time, it could be speculated that service-based objectives will become more important in the future as a main area for competition as globalization leaves less and less room for cost reduction in the long run.

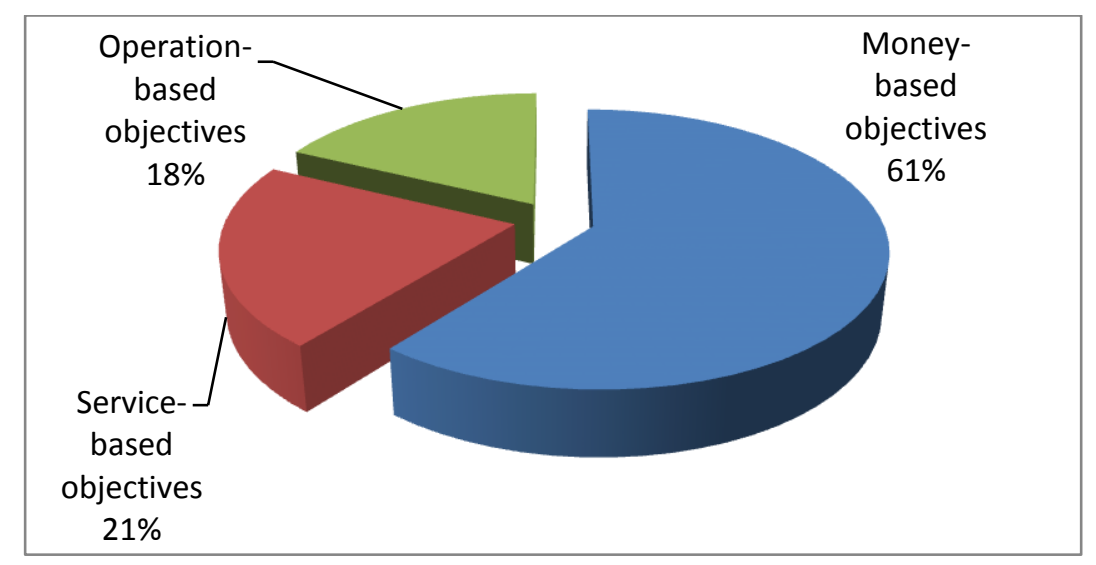

Figure 6. Percentage of the three objective categories considered in the existing literature.

Classical optimization tools have been extensively used in previous work. MIP and MILP are among the most common models in this area. Considering the computational complexity of the decision models for real-life applications, further research is essential to develop efficient algorithms and metaheuristics capable of providing good approximations of Pareto-optimal solutions in a short amount of time. Such developments are crucial for MOO to be considered as a practical decision support for real time decisions which are common in the BTO-SC environment. There is an immediate area for application of MOO to the extant optimization models for BTO-SC problems with a dyadic and network perspective. In this way, the interests of each party can be considered as a separate objective to account for fair treatment of their requirements. A similar approach in dealing with the users' requirements (Finkelstein, et al. 2009) can be applied in this regard.

Almost half of the previous models and algorithms are tested on artificial/synthetic data sets. This indicates another important avenue for further research that is to apply these existing methodologies on real-life data sets to examine their applicability in practice. To this end, industrial collaboration with BTO practitioners is essential to 
provide the research community with real data sets upon which efficient MOO tools can be developed.

Our initial observations of existing software packages for supply chain applications indicate a huge gap in the commercialization of existing and or new MOO methodologies. Part of this gap might be due to the lack of justifiable market for such functionalities from potential users. With expected developments in the solution algorithms combined with superfast computational infrastructures, for example parallel and grid computations, together with the ever increasing importance of informed decision making and future BTO-SC optimization priority research avenues identified here, it could be expected that a promising market for such services emerges in the coming years. Such advances and further research, in turn, can provide the investment justification for the development of MOO-based decision support in future releases of existing SCM software packages.

\section{Acknowledgment}

This research was supported in part by Brunel Research Initiative and Enterprise Fund (BRIEF) under award no. 870. 


\title{
Appendix A. List of Acronyms
}

\author{
AATP : Advanced Available-to-Promise \\ AOC : Advanced Order Commitment \\ APS : Advanced Planning System \\ ATO : Assemble-to-Order \\ ATP : Available-to-Promise \\ BTO : Build-to-Order \\ BTO-SC : Build-to-Order Supply Chain \\ BTO-SCM : Build-to-Order Supply Chain Management \\ DB : Data Base \\ DSS : Decision Support System \\ EA : Evolutionary Algorithm \\ GA : Genetic Algorithm \\ GUI : Graphical User Interface \\ KB : Knowledge Base \\ LP : Linear Programming \\ MB : Model Base \\ MC : Mass Customization \\ MIFP : Mixed Integer Fuzzy Programming \\ MILP : Mixed Integer Linear Programming \\ MIP : Mixed Integer Programming \\ MODE : Multiobjective Differential Evolution \\ MOEA : Multiobjective Evolutionary Algorithm \\ MOGA : Multiobjective Genetic Algorithm \\ MOLP : Multiobjective Linear Programming \\ MOO : Multiobjective Optimization \\ MOOP : Multiobjective Optimization Problem \\ MPS : Master Production Schedule \\ MRP : Material Requirements Planning \\ MRP-II : Manufacturing Resources Planning \\ MTO : Make-to-Order \\ MTS : Make-to-Stock \\ NSGA : Nondominated Sorting Genetic Algorithm \\ PC : Personal Computer \\ SC : Supply Chain \\ SCM : Supply Chain Management
}




\section{References}

Agnetis, A., Detti, P., Meloni, C. \& Pacciarelli, D. (2001), 'Set-up coordination between two stages of a supply chain', Annals of Operations Research 107(1-4), 1532.

Aigbedo, H. (2007), 'An assessment of the effect of mass customization on suppliers inventory levels in a JIT supply chain', European Journal of Operational Research $181,704-715$.

Akkermans, H., Bogerd, P. \& Doremalen, J. V. (2004), 'Travail, transparency and trust: A case study of computer-supported collaborative supply chain planning in high-tech electronics', European Journal of Operational Research 153, 445-456.

Amodeo, L., Chen, H. \& El Hadji, E. (2007), Multi-objective supply chain optimization: An industrial case study, in M. Giacobini, ed., 'EvoWorkshops', Vol. 4448 of LNCS, Springer-Verlag, Berlin Heidelberg, pp. 732-741.

Amodeo, L., Prins, C. \& S'anchez, D. R. (2009), Comparison of metaheuristic approaches for multiobjective simulation-based optimization in supply chain inventory management, in M. Giacobini, ed., 'EvoWorkshops', Vol. 5484 of LNCS, Springer-Verlag, Berlin Heidelberg, pp. 798-807.

Anderson, S. R., Kadirkamanathan, V., Chipperfield, A., Sharifi, V. \& Swithenbank, J. (2005), 'Multi-objective optimization of operational variables in a waste incineration plant', Computers \& Chemical Engineering 29, 1121-1130.

Babu, B. V. \& Gujarathi, A. M. (2007), Multi-objective differential evolution (MODE) for optimization of supply chain planning and management, in 'Proceedings of IEEE Congress in Evolutionary Computation (CEC)', pp. 2732-2739.

Bonczek, R. H., Holsapple, C. W. \& Whinston, A. B. (1980), 'The evolving roles of models in decision support systems', Decision Siences 11, 337-356.

Chakravarty, A. K. \& Balakrishnan, N. (2001), 'Achieving product variety through optimal choice of module variations', IIE Transactions 33, 587-598.

Chen, C. Y., Zhao, Z. Y. \& Ball, M. O. (2001a), 'Quantity and due date quoting available to promise', Information Systems Frontiers 4, 477-488.

Chen, C. Y., Zhao, Z. Y. \& Ball, M. O. (2002), 'A model for batch advanced available-to-promise', Production and Operations Management 11, 1059-1478.

Chen, F., Federgruen, A. \& Zheng, Y.-S. (2001b), 'Coordination mechanisms for a distribution system with one supplier and multiple retailers', Management Science 47(5), 693-708.

Chena, R. S., Lua, K. Y., Yua, S. C., Tzenga, H. W. \& Chang, C. C. (2003), 'A case study in the design of BTO/CTO shop floor control system', Information \& Management 41, 25-37. 
Choi, T. Y. \& Hong, Y. (2002), 'Unveiling the structure of supply networks: case studies in Honda, Acura, and DaimlerChrysler', Journal of Operations Management 20, 469-493.

Chow, H. K. H., Choy, K. L. \& Lee, W. B. (2007), 'Knowledge management approach in build-to-order supply chains', Industrial Management \& Data System 107, 882-919.

Christensen, W. J., Germain, R. \& Birou, L. (2005), 'Build-to-order and just-in-time as predictors of applied supply chain knowledge and market performance', Journal of Operations Management 23, 470-481.

Coello Coello, C. A., Van Veldhuizen, D. A. \& Lamont, G. B. (2002), Evolutionary Algorithms for Solving Multi-Objective Problems, Kluwer Academic Publishers, New York.

Collette, Y. \& Siarry, P. (2004), Multiobjective Optimization: Principles and Case Studies, Springer. Crnkovic, J., Tayi, G. K. \& Ballou, D. P. (2008), 'A decisionsupport framework for exploring supply chain tradeoffs', International Journal of Production Economics 115, 28-38.

Da Cunha, C., Agard, B. \& Kusiak, A. (2007), 'Design for cost: Module-based mass customization', IEEE Transactions on Automation Science and Engineering 4, 350359.

Deb, K. (2001), Multi-Objective Optimization Using Evolutionary Algorithms, Wiley, Chichester, UK.

Demirli, K. \& Yimer, A. D. (2008), 'Fuzzy scheduling of a build-to-order supply chain', International Journal of Production Research 46(14), 3931-3958.

Ding, H., Benyoucef, L. \& Xie, X. (2006), 'A simulation-based multi-objective genetic algorithm approach for networked enterprises optimization', Engineering Applications of Artificial Intelligence 19, 609-623.

Ding, H., Benyoucef, L. \& Xie, X. (2009), 'Stochastic multi-objective productiondistribution network design using simulation-based optimization', International Journal of Production Research 47(2), 479-505.

Diponegoro, A. \& Sarker, B. R. (2006), 'Finite horizon planning for a production system with permitted shortage and fixed-interval deliveries', Computers \& Operations Research 33, 23872404.

Easton, F. \& Moodie, D. R. (1999), 'Pricing and lead time decisions for make-toorder firms with contingent orders', European Journal of Operational Research 116, 305-318. 
Finkelstein, A., Harman, M., Mansouri, S. A., Ren, J. \& Zhang, Y. (2009), 'A search based approach to fairness analysis in requirement assignments to aid negotiation, mediation and decision making', Requirements Engineering 14(4), 231-245.

Galasso, F., Merce, C. \& Grabot, B. (2008), 'Decision support for supply chain planning under uncertainty', International Journal of Systems Science 39(7), 667-675.

Graman, G. A. (2010), 'A partial-postponement decision cost model', European Journal of Operational Research 201(1), 34-44.

Gunasekaran, A. \& Ngai, E. W. T. (2005), 'Build-to-order supply chain management: a literature review and framework for development', Journal of Operations Management 23, 423-451.

Gunasekaran, A. \& Ngai, E. W. T. (2009), 'Modeling and analysis of build-to-order supply chains', European Journal of Operational Research 195, 319-334.

Ha, A. Y., Li, L. \& Ng, S. M. (2003), 'Price and delivery logistics competition in a supply chain', Management Science 49, 1139-1153.

Hegedus, M. G. \& Hopp, W. J. (2001), 'Due date setting with supply constraints in systems using MRP', Computers \& Industrial Engineering 39, 293-305.

Joines, J. A., Gupta, D., Gokce, M. A., King, R. E. \& Kay, M. G. (2002), Supply chain multiobjective simulation optimization, in E. Y“ucesan, C.-H. Chen, J. L. Snowdon \& J. M. Charnes, eds, 'Proceedings of the 2002 Winter Simulation Conference', pp. 1306-1314.

Kawtummachai, R. \& Van Hop, N. (2005), 'Order allocation in a multiple-supplier environment', International Journal of Production Economics 93, 231-238.

Kingsman, B., Hendry, L., Mercer, A. \& De Souza, A. (1996), 'Responding to customer enquiries in make-to-order companies problems and solutions', International Journal of Production Economics 46, 219-231.

Lamothe, J., Hadj-Hamou, K. \& Aldanondo, M. (2006), 'An optimization model for selecting a product family and designing its supply chain', European Journal of Operational Research 169, 1030-1047.

Lee, H. L., Padhamanabhan, V. \& Whang, S. (1997), 'The bullwhip effect in supply chains', Sloan Management Review (Spring), 93-102.

Little, J. D. C. (2004), 'Models and Managers: The Concept of a Decision Calculus', Management Science 50, 1841-1853.

Lu, Y. \& Song., J. S. (2005), 'Order-based cost optimization in assemble-to-order systems', Operations Research 53(1), 151-169.

Masaru, T. \& Masahiro, H. (2003), Genetic algorithm for supply planning optimization under uncertain demand, in E. Cantú-Paz, ed., 'Proceedings of the 
Genetic and Evolutionary Computation Conference (GECCO)', Vol. 2724 of LNCS, Springer-Verlag, Berlin Heidelberg, pp. 2337-2346.

Meyr, H. (2004), 'Supply chain planning in the German automotive industry', OR Spectrum 26, 447-470.

Moodie, D. R. \& Bobrowski, P. M. (1999), 'Due date demand management: negotiating the tradeoff between price and delivery', International Journal of Production Research 37(5), 997-1021.

Moses, S., Grant, H., Gruenwald, L. \& Pulta, S. (2004), 'Real-time due-date promising by build-to-order environments', International Jurnal of Production Research 42(20), 4353-4375.

Mukhopadhyay, S. K. \& Setoputro, R. (2005), 'Optimal return policy and modular design for build-to-order products', Journal of Operations Management 23, 496-506.

Nagarajan, M. \& Bassok, Y. (2008), 'A bargaining framework in supply chains: The assembly problem’, Management Science 54, 1482-1496.

Pibernik, R. (2005), 'Advanced available-to-promise: Classification, selected methods and requirements for operations and inventory management', International Journal of Production Economics 93, 239-252.

Rajagopalan, S. (2002), 'Make to order or make to stock: Model and application', Management Science 48, 241-256.

Rudberg, M. \& Thulin, J. (2009), 'Centralised supply chain master planning employing advanced planning systems', Production Planning \& Control 20(2), 158167.

Sadeh, N. M., Hildum, D.W. \& Kjenstad, D. (2003), 'Agent-based e-supply chain decision support', Journal of Organizational Computing and Electronic Commerce 13(3-4), 225-241.

Sahin, F., Robinson, E. P. \& Gao, L. (2008), 'Master production scheduling policy and rolling schedules in a two-stage make-to-order supply chain', International Journal of Production Economics 115, 528-541.

Selim, H., Araz, C. \& Ozkarahan, I. (2008), 'Collaborative production-distribution planning in supply chain: A fuzzy goal programming approach', Transportation Research Part E 44, 396- 419.

Serrano, V., Alvarado, M. \& Coello Coello, C. A. (2007), Optimization to manage supply chain disruptions using the NSGA-II, in 'Theoretical Advances and Applications of Fuzzy Logic and Soft Computing', Vol. 42 of Advances in Soft Computing, Springer, Berlin Heidelberg, pp. 476-485. 
Sharif, A. M., Irani, Z. \& Lloyd, D. (2007), 'Information technology and performance management for build-to-order supply chains', International Journal of Operations \& Production Management 27, 1235-1253.

Sharma, A. \& LaPlaca, P. (2005), 'Marketing in the emerging era of build-to-order manufacturing', Industrial Marketing Management 34(5), 476-486.

Song, J. S. \& Yao, D. (2002), 'Performance analysis and optimization of assemble-toorder systems with random lead times', Operations Research 50, 889-903.

Song, Z. \& Kusiak, A. (2010), 'Mining Pareto-optimal modules for delayed product differentiation', European Journal of Operational Research, 201(1), 123-128.

Stefansson, H., Jensson, P. \& Shah, N. (2009), 'Procedure for reducing the risk of delayed deliveries in make-to-order production', Production Planning \& Control 20(4), 332-342.

Swaminathan, J. M. \& Tayur, S. R. (2003), 'Models for supply chains in e-business', Management Science 49(10), 1387-1406.

Turban, E. \& Aronson., J. E. (2001), Decision support systems and intelligent systems, Prentice Hall.

Tyan, J. C. \& Duc, F.-K. W. T. C. (2003), 'An evaluation of freight consolidation policies in global third party logistics', Omega 31, 55-62.

Venkatadri, U., Srinivasan, A., Montreuil, B. \& Saraswat, A. (2006), 'Optimizationbased decision support for order promising in supply chain networks', International Journal of Production Economics 103, 117-130.

Wang, D., Fang, S.-C. \& Hodgson, T. J. (1998), 'A fuzzy due-date bargainer for the make-to-order manufacturing systems', IEEE Transactions on Systems, Man, and Cybernetics - Part C: Applications and Reviews 28(3), 492-497.

Watanapa, B. \& Techanitisawad, A. (2005), 'Simultaneous price and due date settings for multiple customer classes', European Journal of Operational Research 166, 351368 .

Xue, F., Sanderson, A. C. \& Graves, R. J. (2009), 'Multiobjective evolutionary decision support for design-supplier-manufacturing planning', IEEE Transactions on Systems Man and Cybernetics-Part A: Systems and Humans 39, 309-320.

Zhao, Z., Ball, M. O. \& Kotake, M. (2005), 'Optimization-based available-to-promise with multistage resource availability', Annals of Operations Research 135, 65-85.

Zhou, C. C., Yin, G. F. \& Hu, X. B. (2009), 'Multi-objective optimization of material selection for sustainable products: Artificial neural networks and genetic algorithm approach', Materials and Design 30, 1209-1215. 
Zhou, G., Min, H. \& Gen, M. (2003), 'A genetic algorithm approach to the bi-criteria allocation of customers to warehouses', International Journal of Production Economics 86, 35-45. 